would rise from $£ 84 \cdot 1$ million in $1961-62$ to an estimated minimum of about $£ 130$ million in 1966-67. Student numbers would increase from 111,385 to 150,000 in the same period. The universities had estimated that the entry in 1966 should be more than 10,000 higher and would represent about the same percentage of the much larger ago-group.

\section{British Medical Aid to the Developing Countries}

Is opening an adjournment debate on medical aid to the developing countries in the House of Commons on February 11, Mr. J. Boyden concentrated on the report of Sir Arthur Porritt and his Working Party, ondorsing an earlier tribute of the Socretary for Technical Cooperation to the work of Sir Arthur and his colleagues. Mr. Boyden emphasized the urgency of the problem, pointing out that the Working Party itself had noted a further decline in British influence in the medical field overseas during the four months it was at work. Replying for the Government in the absence of Mr. D. Vosper through illness, the Joint Parliamentary Secretary to the Ministry of Health, Mr. B. Braine, said that the Government's policy in providing technical assistance was to meet the requests of developing countries in whatever form they appeared. The delay in publishing the report was due to the new financial provision involved which could be considered only in the context of the estimates of the Department of Technical Co-operation for 1963-64. Mr. Vosper would not have been able to make a statement had he been present, but would do so at the earliest opportunity, and meanwhile, Mr. Braine said that the Government accepted the greater part of the recommondations in the report.

To-day, 900 undergraduate students from ovorseas are studying in Britain's medical schools and thero are 9,000 student nurses from oversoas in Britain's hospitals. Almost half the doctors at registrar level in the hospitals are from overseas, and in the past two years the Department for Technical Co-operation has arranged and paid for postgraduate training for 265 doctors and 170 nursing sisters from overseas, in addition to 170 doctors from the dependent territories for postgraduato training at the expense of their own Governments. Under the Overseas Assistance Scheme, 1,385 medical staff have been designated for the coming year at a cost of $£ 1.6$ million. The Department also recruited 131 doctors during the past two years for service overseas, and many medical appointments were made under the Colombo Plan and the Special Commonwealth African Assistance Plan, while medical equipment to the value of $£ 68,000$ was provided under these plans in 1961-62, and $£ 262,000$ is at present boing expended on medical research for the benefit of developing countries.

Mr. Braine admitted to some disappointment in the response to serve overseas. The Government proposed to creato 25 bursaries for postgraduates from the developing countries, and these would be administered on lines similar to those provided under the Colombo Plan. The supervision of postgraduate education in non-teaching hospitals, he said, was now in hand with tho aid of $£ 250,000$ provided by the Nuffield Provincial Hospitals Trust. The Government was aiming at establishing 12 senior and 6 junior lectureships in 1963-64 at the two schools of tropical medicine as a contribution to preventive medicine overseas. If all the 235 vacancios at present existing were to be filled, a climate of opinion must be created in the medical profession and the hospital boards as favourable to service overseas as that already created in the teaching profession, and to that end Mr. Braine welcomed the publicity afforded by the debate.

\section{Reactor at Full Power at Buchanan, New York}

FULL power operation has been achieved at Con Edison's Indian Point atomic-electric generating station in Buchanan, New York, thirty-five iniles from the contre of New York City. At full power, Indian Point generates $275,000 \mathrm{~kW}$ for Con Edison's six million $\mathrm{kW}$ system serving the area of New York City. The steam which drives the turbine at Indian Point receives approximately two-thirds of its heat from tho atomic reactor and onethird from oil-fired superheaters. The reactor, according to its designer and builder, the Babcock and Wilcox Co., has operated smoothly since it achieved criticality. The core of the reactor, the first power reactor to use thorium as fuel, will last approximately two years without refuelling.

\section{The Imperial College of Science and Technology}

A BRochure, A Decade of Expansion: 1953-1963, Imperial College, describes, with diagrams and illustrations, the progress made since January 1953 with the expansion of the Imperial College of Science and Technology from about 1,650 full-time students to 3,000 (Pp. 36. London: Imperial Colloge, 1963). This target has almost been achieved. Academic work has at no stage been interrupted, while standards have been maintained and oven improved, and many pioneering academic ventures have beon startod. In South Kensington the area has grown from 9 to 25 acres and the floor space from 800,000 to almost 1.8 million sq. ft. gross, and many semi-obsolete buildings have been replaced. While these developments have beon achieved basically through national funds made available through the University Grants Committee, substantial help has come from charitable foundations, industry, and private individuals. Capital expenditure on buildings of more than $£ 17$ million was involved. The academic staff of 491 includes 51 profossors and 75 readers, and there aro some 1,100 postgraduate students, and the total of 2,900 students includes 659 from overseas, whilo the annual income for supported research exceeds $£ 500,000$, half of which comes from the Department of Scientific and Industrial Research. Despite this encouraging picture when the brochure looks to the future, it points out that the grants announced for the new quinquennium $1962-67$ are so low that the College will be unable to man completely the large, and sometimes unique, new buildings which have been or are being completed. This will have a serious effect on the admission of students and the quality of the specialist postgraduate education provided; the Departments of Mathematies and of Chemistry would be special sufferers. Remedial action is urgently needed if the full benefits of the expansion are to be realizod, and, in its absence, it is anticipated that the number of students will not exceed 3,100 , whereas on the recurrent grant applied for a total of 3,700 was visualized. Reference is also made to the social needs of students. By the end of 1962-63 rosidence should be provided for 22 per cent of the students, perhaps about one-third of the demand, but unless finance permits the expansion of the College to be resumed these figures will have deteriorated by the end of the quinquennium.

\section{Hazards to Health due to Radiation}

The first edition of the Code of Practice against Radiation Hazards for the guidance of members of the Imperial College of Science and Technology, University of London, was issued in June 1957. The latest edition, the fourth (October 1962), supersedos formor editions and gives tho regulations applicable to the use of equipmont producing ionizing radiation, to accelorators, and to the use of sealed and unsealed radioactive isotopos. The first eight pages of the booklet contain the Code, which is mandatory. The purpose of the Code is to control the hazards to health arising from radiation, to ensure the safo disposal of waste material and effluent, and to avoid contamination of laboratories and their surroundings, and it deals mainly with administrative procedure and instructions. The remainder of the booklet consists of oleven appondixes, 